\title{
Effectual components of Polygonum ciliinerve protects against Staphylococcus aureus infection with immunomodulatory functions in C57BL/6 mice $^{1}$
}

\author{
Lanxiu Cao', Juan IV", Xian Zhao", Jiang Wang"', Li Ma"
}

'PhD, Department of Chinese Materia Medica, Shanxi University, Traditional Chinese Medicine, Shanxi, China. Conception and design of the study, acquisition of data, technical procedures, manuscript preparation and writing, final approval. "Graduate student, Department of Chinese Materia Medica, Shanxi University, Traditional Chinese Medicine, Shanxi, China. Technical procedures, acquisition of data.

IIIPhD, Department of Chinese Materia Medica, Shanxi University, Traditional Chinese Medicine, Shanxi province, China. Statistical analysis, interpretation of data.

\section{Abstract}

Purpose: To investigate the efficacy and mechanisms of root tuber of Polygonum ciliinerve (Nakai) ohwi (rPC) which has been used to treat bacterial infection in traditional Chinese medicine.

Methods: With the mouse model of Staphylococcus aureus (S. aureus) pneumonia, the phenotype of rPC treated mice, including body weight, mortality, lung slices and bacterial burden were evaluated. Furthermore, inflammatory factors in bronchoalveolar lavage (BAL) were determined by ELISA and the distribution of T cells in lung was assessed by immunofluorescence assay.

Results: rPC treatment could dose-dependently reduce weight loss and mortality in S. aureusinfected mice. Upon $10 \mathrm{mg} / \mathrm{ml} \mathrm{rPC}$ treatment, S. aureus-infected mice showed about 8 grams increase in body weight $(P<0.001)$ and $50 \%$ enhancement in mortality. The integrity of lung tissue and bacterial burden were also improved by rPC treatment. Moreover, rPC was found to modulate the immune response in infection.

Conclusion: rPC has therapeutic potential for $S$. aureus infections and pneumonia with immunomodulatory functions.

Key words: Polygonum. Staphylococcus aureus. Infection. Immunomodulation. Mice. 


\section{Introduction}

The gram-positive pathogen $S$. aureus is one of leading cause of infectious diseases worldwide, ranging from skin abscesses to life-threatening illnesses such as sepsis, pneumonia and endocarditis ${ }^{1}$. It is estimated half of the population worldwide carries $S$. aureus on the $\mathrm{skin}^{2}$. S. aureus is also one of the major pathogens for the contamination of a great variety of foods ${ }^{3}$. Increasing incidence of foodborne diseases associated with $S$. aureus has been reported in many countries ${ }^{4}$. Though a number of antibacterial agents have been approved in the past decades, drug resistance poses a problem in their long-term use. Therefore, it is necessary to identify new antibacterial agents with novel mechanisms to kill S. aureus effectively and permanently.

Polygonum ciliinerve (Nakai) ohwi belongs to Polygonum of Polygonaceae. P. ciliinerve is widely used in Chinese herbal medicine and is mainly distributed in Qinling Mountains. According to Bencao Tujing, which was published in 1061, rPC has been used as heat-clearing and detoxicating prescription in traditional Chinese medicine. The most effective chemical ingredients of $\mathrm{rPC}$ are polysaccharide and anthraquinones, including emodin, chrysophanol, physcion, rhein, and so forth $^{5,6}$. With the immunomodulatory effect of polysaccharide and the antimicrobial activity of anthraquinones, rPC has been found to possess antimicrobial, antiviral, antioxidant and antitumor activities ${ }^{6-9}$. However, these studies mainly focused on the in vitro effect of rPC. The in vivo effect and underlying mechanisms of rPC are still poorly understood.

This study aimed to evaluate the protective effect of rPC in a S. aureus-infected mouse model and explore the potential mechanism of rPC. The treatment of rPC sets an innovative example for herbal medicine to treat infectious diseases relying on immunomodulatory properties.

\section{Methods}

\section{Preparation of $r P C$}

rPC was purchased from $\mathrm{Hu}$ Qing Yu Chinese Pharmacy. The root (100g) was pulverized and extracted twice with $30 \%$ ethanol in a reflux condenser at $100^{\circ} \mathrm{C}$ for $3 \mathrm{~h}$. The extraction was filtered through $50 \mu \mathrm{m}$ filters and concentrated as lyophilized powder. The final dried material was resuspended in $0.5 \%$ sodium carboxymethyl cellulose solution.

\section{Bacterial strain}

S. aureus ATCC6538 was the experimental bacteria used throughout our study, which was used for the evaluation of antibacterial effects ${ }^{10}$. S. aureus was incubated in Luria Broth at $37^{\circ} \mathrm{C}$ with $200 \mathrm{rpm}$ shaking for 15h. The number of colony forming unit (CFU) was calculated through a standard growth curve.

\section{Mouse model of S. aureus pneumonia}

6-week old C57BL/6 mice were purchased from Charles River. All mice were maintained in specific pathogen-free (SPF) conditions. The operation of animal experiment conformed to the Animal Care and Use Committee of Shanxi University of Traditional Chinese Medicine

$2 \times 10^{7} \mathrm{cfu}$ of $S$. aureus in $50 \mu \mathrm{PBS}$ was used to intranasally infect 6-week old C57BL/6 mice for $24 \mathrm{~h} .2 \mathrm{~mL}$ of $\mathrm{rPC}(0,1 \mathrm{mg} / \mathrm{mL}, 5 \mathrm{mg} / \mathrm{ml}$, $10 \mathrm{mg} / \mathrm{ml}$ ) was administered through gavage after infection once a day. $7.5 \times 10^{7} \mathrm{cfu}$ of $S$. aureus was used to perform mortality studies.

\section{Histologic examination}

Lungs were aseptically removed and fixed in 4\% paraformaldehyde and embedded in paraffin. Paraffin-embedded tissue was cut at 5 microns. Then, hematoxylin and eosin were 
stained for the evaluation of histomorphology.

\section{$B A L$ collection and CFU analysis}

BAL was collected using 22-g venous catheters through washing lungs with $3 \mathrm{ml}$ RPMI-1640 (Gibco) and protease inhibitors (Roche) as early described ${ }^{11}$. BAL was serially diluted and plated on Luria Broth-agar plates.

\section{Cytokine and chemokine analysis}

BAL was centrifuged at $1000 \times g$ for 10 min and cell-free supernatant was obtained. Cytokine levels of MCP-1,TNF- $\alpha$ and IL- 6 were determined by ELISA kits (R\&D Systems).

Immunohistochemistry

Lung sections were blocked with $10 \%$ goat serum at $37^{\circ} \mathrm{C}$ for $45 \mathrm{~min}$ and incubated with primary antibody (CD4/CD8, Cell Signaling Technology) overnight at $4^{\circ} \mathrm{C}$. Subsequently, the secondary antibody (IgG-PE/FITC, Cell Signaling Technology) was added and incubated at room temperature for 2h. Finally, DAPI (Thermo Fisher Scientific) staining was performed for 20 min at room temperature. Images were taken by FV1200 (Olympus).

Statistical analysis

Data in this study are expressed as means \pm SEM. Mann-Whitney test was used to evaluate the significance of data between two groups. Multiple comparisons were performed with One-way ANOVA. The survival curve was estimated by Kaplan-Meier methods. Statistics were performed with SPSS and Prism software and $p$ value $<0.05$ was considered significant.

\section{Results}

rPC protects mice from S. aureus lung infection

To evaluate the efficacy of rPC in vivo, 6-week-old C57BL/6 mice were intranasally infected with $2 \times 10^{7} \mathrm{cfu}$ of exponential-phase $S$. aureus to establish a model of $S$. aureus pneumonia. The ethanol extraction of $\mathrm{rPC}$ with different concentrations $(0,1 \mathrm{mg} / \mathrm{mL}, 5 \mathrm{mg} / \mathrm{ml}$ or $10 \mathrm{mg} / \mathrm{ml}$ ) treated $S$. aureus-infected mice daily. Mice were monitored for body weight and survival every two days (Figure 1). S. aureus infection caused serious weight loss, while rPC treatment dose-dependently reduced this symptom (Figure 1A). Infection of $S$. aureus also led to $60 \%$ mortality in mice. However, treatment with different concentrations of rPC (1 $\mathrm{mg} / \mathrm{mL}, 5 \mathrm{mg} / \mathrm{ml}$ or $10 \mathrm{mg} / \mathrm{ml}$ ) decreased mortality to $50 \%, 40 \%$ and $10 \%$, respectively (Figure 1B). The higher body weight and lower mortality indicate the protective effects of $\mathrm{rPC}$ in the $S$. aureus infection.
A

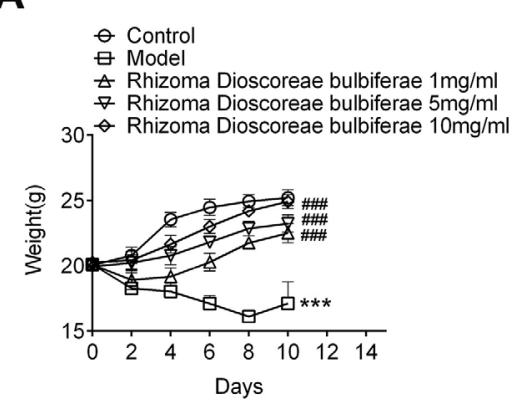

B

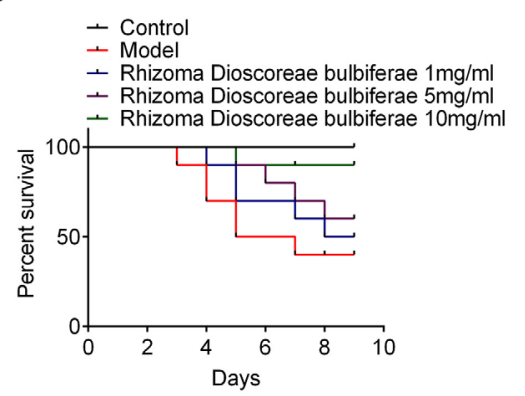

Figure 1 - rPC protects mice from S. aureus lung infection. (A) Body weight of mice was monitored every two days $(n=10)$. (B) Mice survival was monitored every two days after infection $(n=10) .{ }^{* * *} p<0.001$ compared with control group. \#\#\# $p<0.001$ compared with $S$. aureus infection group. 
rPC alleviates the pathologic symptoms of pneumonia in S. aureus-infected mice

To gain further insight into the protective effects of rPC in the mouse model of $S$. aureus pneumonia, lung was aseptically collected for histopathology. Compared with uninfected mice, $S$. aureus infection thickened the alveolar walls, increased the lung interstitium and reduced alveolar space (Figure 2A). These symptoms were ameliorated after $\mathrm{rPC}$ treatment in a dose-dependent manner (Figure 2A). Three days after infection, mice were sacrificed and CFU of $S$. aureus was determined in BAL. Bacterial load in BAL of $S$. aureus-infected mice was significantly higher than the rPC-treated and control groups (Figure 2B). Consequently, rPC treatment effectively assisted mice in eliminating $S$. aureus. These results suggest that rPC could alleviate the pathologic symptoms of pneumonia through reducing the bacterial burden in mice.
A

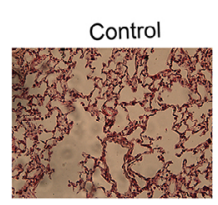

Model

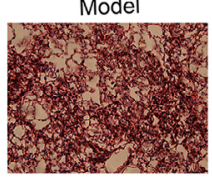

$\mathrm{rPC} 5 \mathrm{mg} / \mathrm{ml}$

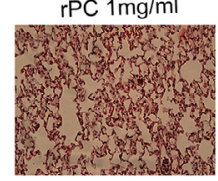

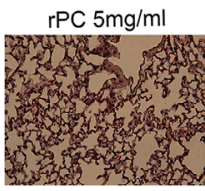

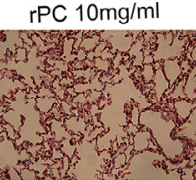

B

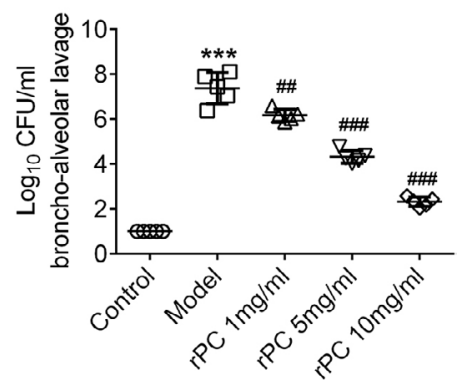

Figure 2 - rPC alleviates the pathologic symptoms of pneumonia in S. aureus-infected mice. (A) The morphology of lung in response to $S$. aureus challenge and rPC treatment. (B) The bacterial burden was measured in BAL 72 hours after infection. ${ }^{* * *} \mathrm{p}<0.001$ compared with control group. \#\#\# $\mathrm{p}<0.001$ compared with $S$. aureus infection group.

Modulation of cytokine and chemokine imbalance in S. aureus-infected mice with rPC treatment

To better characterize the correlation of immune response with rPC treatment, we assessed the concentrations of cytokines and chemokine in BAL 24 and 72 hours after $S$. aureus infection. The secretion of proinflammatory cytokines (TNF $\alpha$ and IL-6) and monocyte-associated chemokine (MCP-1/
CCL2) was significantly increased after $S$. aureus infection (Figure $3 \mathrm{~A}$ and $\mathrm{B}$ ). In contrast, rPCtreated mice showed a dose-dependent decrease in TNF $\alpha$, IL- 6 and MCP-1 levels compared to $S$. aureus-infected mice, which is consistent with the aforementioned symptoms (Figure 3A and B). rPC treatment induced lower levels of cytokines and chemokine, similar to control group, indicating that rPC plays an important role in modulating the immune response induced by $S$. aureus. 
A
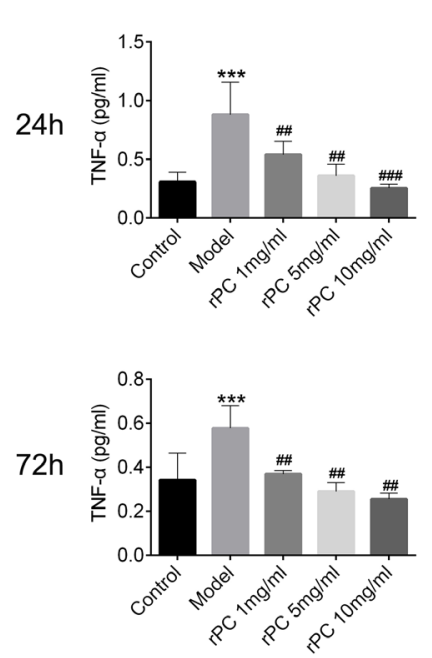

B
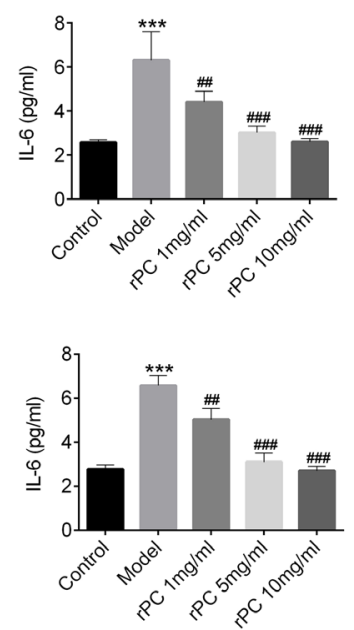

C
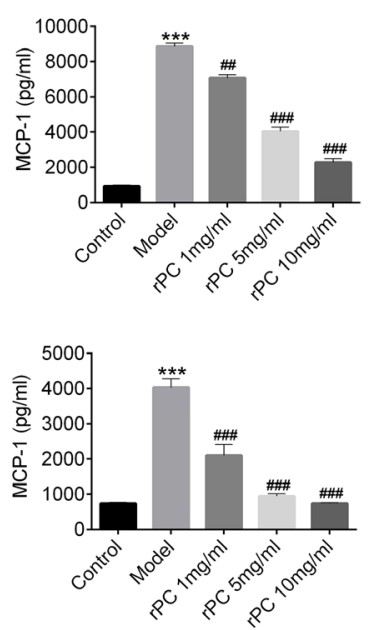

Figure 3 - Cytokine and chemokine responses to $S$. aureus infection. Cytokines and chemokine were analyzed in BAL 24 and $72 \mathrm{~h}$ after infection. (A) The level of TNF- $\alpha$. (B) The level of IL-6. (C) The level of MCP-1. ${ }^{* * *} p<0.001$ compared with control group. \#\#\# $\mathrm{p}<0.001$ compared with $\mathrm{S}$. aureus infection group.

rPC treatment modulates the ratio of CD4/CD8 $T$ cells in S. aureus-infected mice

$T$ cells play an important role in resistance to infection for eliminating bacteria or infected cells ${ }^{12}$. Thus, we determined the distribution of $\mathrm{CD} 4^{+}$and $\mathrm{CD} 8^{+} \mathrm{T}$ cells in the lung of $S$. aureus-infected mice. S. aureus challenge mainly increased $\mathrm{CD} 4^{+} T$ cell density in the lung
(Figure 4A and B). However, rPC treatment dose-dependently reduced the number of $\mathrm{CD} 4^{+}$ $T$ cells and increased the density of $C D 8^{+} T$ cells (Figure $4 \mathrm{~A}$ and B). Given that $\mathrm{CD} 8^{+}$cytotoxic $T$ cells confer more effective cytotoxicity than $\mathrm{CD}^{+}$helper $\mathrm{T}$ cells, these results indicate that rPC could modulate the immune response induced by $S$. aureus through altering the ratio of CD4/CD8 $T$ cells.
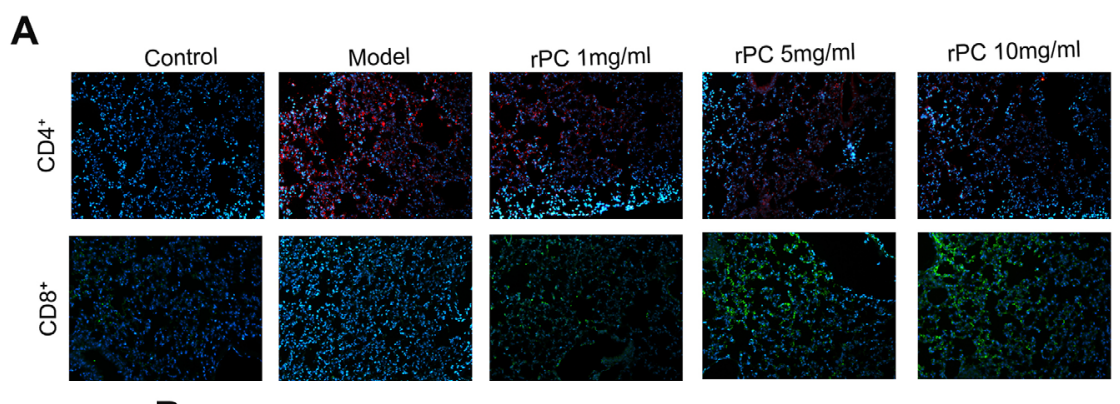

B
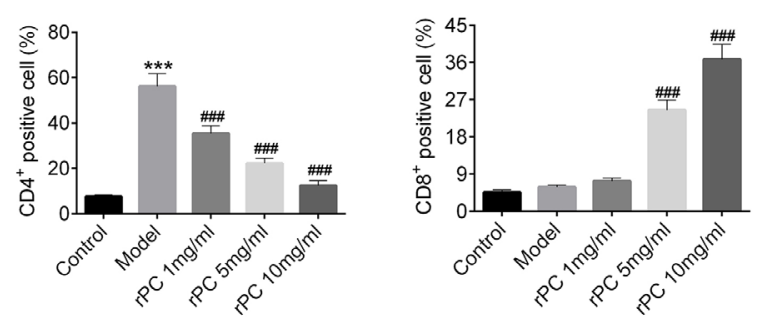

Figure 4 - rPC treatment modulates the ratio of CD4/CD8 T cells in S. aureus-infected mice. (A) The appearance of $\mathrm{CD}^{+}$and $\mathrm{CD} 8^{+} \mathrm{T}$ cells in lung. Red represents $\mathrm{CD} 4^{+} \mathrm{T}$ cells, green represents $\mathrm{CD} 8^{+} \mathrm{T}$ cells and blue represents nuclei. (B) The percentage of $\mathrm{CD} 4^{+}$and $\mathrm{CD} 8^{+} \mathrm{T}$ cells in lung tissue sections. ${ }^{* * *} p<0.001$ compared with control group. \#\#\# $\mathrm{p}<0.001$ compared with $\mathrm{S}$. aureus infection group. 


\section{- Discussion}

S. aureus is a serious public health problem worldwide which causes increased morbidity and mortality ${ }^{13}$. Despite ongoing research, there is no effective prescription in curing $S$. aureus infection due to its drug resistance ${ }^{14}$. Chinese herbal medicines are difficult to develop antimicrobial resistance and have been used to treat infections successfully ${ }^{15}$. rPC is used as an antibacterial and antipyretic prescription in Chinese traditional medicine, which is expected to be the potential therapeutic application for $S$. aureus infection.

We firstly evaluated the protective effect of rPC in a $S$. aureus pneumonia model. Pneumonia due to $S$. aureus is correlated with poor outcomes, including high cost and significant mortality ${ }^{16}$. Our results suggest that $\mathrm{rPC}$ could protect mice from reduced weight loss and mortality. Disruption of alveolar architecture, consolidation of the lung parenchyma and hemorrhage are the typical pathologies of $S$. aureus pneumonia ${ }^{17}$. In the current study, $S$. aureus challenge destroyed the alveolar structure while rPC could ameliorate lung histopathological lesions and maintain the alveolar integrity of $S$. aureusinfected mice. Higher rPC treatment $(10 \mathrm{mg} /$ $\mathrm{ml}$ ) nearly recovered the original structure of alveolar. Moreover, the bacterial burden in BAL of $S$. aureus-infected mice treated with rPC was far below the quantity in $S$. aureus pneumonia model, indicating that $\mathrm{rPC}$ treatment enhances the clearance of $S$. aureus in vivo.

The immune system plays an important role in protecting against infectious microorganisms while immune imbalance could aggravate the bacterial infection ${ }^{18}$. In the present study, $S$. aureus infection induced increased levels of TNF $\alpha$, IL- 6 and MCP-1, which indicates the recruitment and activation of immune cells in S. aureus-infected mice. In contrast, rPC was able to decrease the levels of proinflammatory cytokines and chemokine, demonstrating the effects of rPC in controlling inflammation and proinflammatory cytokine expression.

In adaptive immunity, $\mathrm{CD} 8^{+} \mathrm{T}$ cells are the key effector cells against virus, protozoan and bacteria ${ }^{12}$ through cytotoxic effects ${ }^{19}$. S. aureus infection increases the populations of $\mathrm{CD}^{+} \mathrm{T}$ lymphocytes while has little impact on $\mathrm{CD}^{+}$T lymphocytes, which is in agreement with our results ${ }^{20,21}$. rPC treatment reduced $\mathrm{CD}^{+} \mathrm{T}$ cell density induced by $S$. aureus, indicating the activation of $T$ helper cells can be suppressed by $\mathrm{rPC}$. However, the elevated level of $\mathrm{CD}^{+}$ $T$ cells suggests that $\mathrm{rPC}$ could reinforce the cytotoxicity of immune system.

Modern pharmacology revealed that polysaccharides are the effective chemical ingredients of $\mathrm{rPC}^{5,6}$. Polysaccharides are believed to own benign biologic properties and have been shown to work as potent immunomodulating agents ${ }^{22}$. Therefore, we inferred that the immunomodulatory functions of rPC mainly depend on the polysaccharides in rPC. However, we couldn't exclude the synergistic effect of other chemical ingredients in rPC.

\section{Conclusions}

Our results demonstrate that the protection of rPC in S. aureus-infected mice is dependent on the immunomodulatory properties of rPC. We posit that rPC could be a promising therapeutic herbal medicine for treating $S$. aureus infection although more work needs to be done to support our findings. Moreover, this study provides an example for the development of herbal medicine as immunomodulatory therapy regimens against bacterial pathogens. 


\section{Reference}

1. Taccetti G, Cocchi P, Festini F, Braggion C, Campana S. Community-associated meticillin-resistant Staphylococcus aureus. Lancet (London, England). 2010;376(9743):767-8. doi: 10.1016/s01406736(10)61371-2.

2. Kuehnert MJ, Kruszon-Moran D, Hill HA, McQuillan G, McAllister SK, Fosheim G, McDougal LK, Chaitram J, Jensen B, Fridkin SK, Killgore G, Tenover FC. Prevalence of Staphylococcus aureus nasal colonization in the United States, 2001-2002. J Infect Dis. 2006;193(2):172-9. doi: 10.1086/499632.

3. Rasooly R, Do PM, Friedman M. Inhibition of biological activity of staphylococcal enterotoxin A (SEA) by apple juice and apple polyphenols. J Agric Food Chem. 2010;58(9):5421-6. doi: 10.1021/ jf904021b.

4. Shinefield HR, Ruff NL. Staphylococcal infections: a historical perspective. Infec Dis Clin North Am. 2009;23(1):1-15. doi: 10.1016/j.idc.2008.10.007.

5. Chen ZF, Gang AS. Content of active component in wild medicinal plant polygonum ciliinerve determined by HPLC and their relationship with tuber size. J Hebei Agric Sci. 2011.

6. Cui JJ, Yuan JF, Zhang ZQ. Extraction and Biological activity of crude polysaccharide from Polygonum ciliinerve. Natural Product Res Development. 2007;19(6):960-4.

7. WangYuliang, Lu MD, Ophthalmology NO. Experimental study on inhibitory effect of Chinese herbs on herpes simplex virus. J Traditional Chinese Ophthalmol. 1995.

8. Shin MS, Park SB, Shin KS. Molecular mechanisms of immunomodulatory activity by polysaccharide isolated from the peels of Citrus unshiu. Int J Biol Macromol. 2018;112:576-83. doi: 10.1016/j. ijbiomac.2018.02.006.

9. Rhea J, Craig Hopp D, Rabenstein J, Smith C, Lucas S, Romari K, Clarke M, Francis L, Irigoyen $\mathrm{M}$, Luche $\mathrm{M}$, Carr GJ, Mocek U. 5-Hydroxy ericamycin, a new anthraquinone with potent antimicrobial activity. J Antibio (Tokyo). 2012;65(12):623-5. doi: 10.1038/ ja.2012.78.

10.Rivadeneira J, Di Virgilio AL, Audisio MC, Boccaccini AR, Gorustovich AA. Evaluation of the antibacterial effects of vancomycin hydrochloride released from agar-gelatinbioactive glass composites. Biomed Mater. 2015;10(1):015011. doi: 10.1088/17486041/10/1/015011.

11.Facchini M, De Fino I, Riva C, Bragonzi A. Long term chronic Pseudomonas aeruginosa airway infection in mice. J Vis Exp. 2014;(85). doi: 10.3791/51019.

12. Harty JT, Tvinnereim AR, White DW. CD8+ $T$ cell effector mechanisms in resistance to infection. Ann Rev Immunol. 2000;18:275-308. doi: 10.1146/annurev. immunol.18.1.275.

13.Prince A, Wang $H$, Kitur $K$, Parker D. Humanized mice exhibit increased susceptibility to Staphylococcus aureus pneumonia. J Infect Dis. 2017;215(9):138695. doi: 10.1093/infdis/jiw425.

14.Fowler VG, Allen KB, Moreira ED, Moustafa $M$, Isgro F, Boucher HW Corey GR, Carmeli Y, Betts R, Hartzel JS, Chan IS, McNeely TB, Kartsonis NA, Guris D, Onorato MT, Smugar SS, DiNubile MJ, Sobanjo-ter Meulen A. Effect of an investigational vaccine for preventing Staphylococcus aureus infections after cardiothoracic surgery: a randomized trial. JAMA. 2013;309(13):1368-78. doi: 10.1001/jama.2013.3010.

15.Cai Y, Zhang Q, Fu Y, Li L, Zhao N, Lu A, Liu $Q$, Jiang $M$. Effectiveness of chinese herbal medicine combined with antibiotics for extensively drug-resistant enterobacteria and nonfermentative bacteria infection: real-life experience in a retrospective cohort. Biomed Res Int. 2017;2017:2897045. doi: $10.1155 / 2017 / 2897045$.

16.Taneja C, Haque N, Oster G, Shorr AF, Zilber S, Kyan PO, Reyes KC, Moore C, Spalding J, Kothari S, Zervos M. Clinical and economic outcomes in patients with community-acquired Staphylococcus aureus pneumonia. J Hosp Med. 2010;5(9):528-34. doi: $10.1002 / \mathrm{jhm} .704$.

17.Garnier F, Tristan A, Francois B, Etienne J, Delage-Corre M, Martin C, Liassine N, Wannet W, Denis F, Ploy MC. Pneumonia and new methicillin-resistant Staphylococcus aureus clone. Emerg Infect Dis. 2006;12(3):498500. doi: 10.3201/eid1205.051040.

18.Abdullah Z, Knolle PA. Scaling of immune responses against intracellular bacterial infection. EMBO J. 2014;33(20):2283-94. 
doi: 10.15252/embj.201489055.

19. Ruiz JH, Becker I. CD8 cytotoxic T cells in cutaneous leishmaniasis. Parasite Immunol. 2007;29(12):671-8. doi: 10.1111/j.13653024.2007.00991.x.

20.Chan LC, Chaili S, Filler SG, Miller LS, Solis $\mathrm{NV}$, Wang $\mathrm{H}$, Johnson $\mathrm{CW}$, Lee $\mathrm{HK}$, Diaz $L F$, Yeaman MR. Innate immune memory contributes to host defense against recurrent skin and skin structure infections caused by methicillin-resistant Staphylococcus aureus. Infec Immun. 2017;85(2). doi: 10.1128/ iai.00876-16.
21.Wang S, Wang Q, Zeng X, Ye Q, Huang S, Yu $H$, Yang T1, Qiao $S$. Use of the antimicrobial peptide sublancin with combined antibacterial and immunomodulatory activities to protect against methicillinresistant Staphylococcus aureus infection in mice. J Agric Food Chem. 2017;65(39):8595605. doi: 10.1021/acs.jafc.7b02592.

22.Tzianabos AO. Polysaccharide immunomodulators as therapeutic agents: structural aspects and biologic function. Clin Microbiol Rev. 2000;13(4):523-33. doi: 0893-8512/00/\$04.0010.

\section{Correspondence:}

Lanxiu Cao

Basic Medical College, Shanxi University,

Traditional Chinese Medicine

Century Avenue, Xianyang City

Shanxi Province China

Phone: 86-029-38185353

LanxiuCaozxc@163.com

Received: July 13, 2018

Review: Sept 15, 2018

Accepted: Oct 16, 2018
Conflict of interest: none

Financial source: Grant No. 2017JM8021 and

No. 2010Jk476

\begin{abstract}
${ }^{1}$ Research performed at Department of Chinese Materia Medica, Shanxi University, Traditional Chinese Medicine, Shanxi, China.
\end{abstract}

